\title{
THE EFFECT OF DIETARY IMMUNOSTIMULANTS ON THE SUSCEPTIBILITY OF COMMON CARP (CYPRINUS CARPIO) TO THE WHITE SPOT PARASITE, ICHTHYOPHTHIRIUS MULTIFILIIS
}

\author{
Dávid Herczeg ${ }^{1}$, Dóra SiPos ${ }^{1}$, Ádám DÁN ${ }^{2}$, Christina LoY $^{3}$, Dennis M. KallerT ${ }^{3}$ \\ and Edit ESZTERBAUER ${ }^{1, *}$ \\ ${ }^{1}$ Institute for Veterinary Medical Research, Centre for Agricultural Research, \\ Hungarian Academy of Sciences, Hungária krt. 21, H-1143 Budapest, Hungary; \\ ${ }^{2}$ National Food Chain Safety Office, Budapest, Hungary; \\ ${ }^{3}$ Kallert \& Loy GbR, Adelsdorf, Germany
}

(Received 12 July 2017; accepted 24 October 2017)

\begin{abstract}
One of the main obstacles in freshwater aquaculture is the parasitic ciliate Ichthyophthirius multifiliis (Ich), the causative agent of white spot disease. The use of immunostimulants as feed additives may be a promising approach to control Ich infection. In the present study, we tested the prophylactic effect of orally administered $\beta-1,3 / 1,6$-glucan and propolis extract E50 against Ich infection in common carp. In total, 122 fish were separated into three experimental groups fed with a control, $3 \% \beta$-glucan and $1 \%$ propolis diet for 40 consecutive days, respectively. On day 40, 16 fish per group were individually exposed to Ich theronts and the number of trophonts was counted 5 days post exposure. Relative gene expression of interleukin 1- $\beta$ (IL-1- $\beta$ ) in common carp liver was examined by qPCR. Compared to control, the mean infection intensity was lower in the $\beta$-glucan- and propolis-fed groups; however, the difference was not statistically significant. The relative expression of IL-1- $\beta$ significantly decreased in the propolis-fed group at day 10 . In the $\beta$-glucan-fed group, a significant IL-1- $\beta$ decrease was detected at day 15 compared to control. Although the Ich infection intensity was slightly decreased in both treated groups, and IL-1- $\beta$ was moderately down-regulated in the liver of common carp, our results suggest that the applied feeding regime is insufficient to prevent Ich outbreaks in common carp.
\end{abstract}

Key words: Ich, common carp, white spot disease, immunostimulants, $\beta$ glucan, propolis extract E50

The parasitic ciliate, Ichthyophthirius multifiliis (Fouquet, 1876), commonly known as Ich, is the highly pathogenic fish endoparasite responsible for white spot disease. As a generalist pathogen, it occurs over a wide geographic range and infects numerous freshwater fish species due to its low host specifici-

*Corresponding author; E-mail: eszterbauer.edit@agrar.mta.hu; Phone: 0036 (1) 467-4067, 0036 (1) 467-4090 
ty. It causes severe declines among natural fish populations and significant economic losses in freshwater aquaculture (Matthews, 2005). Although naive fish often die following parasite exposure, individuals surviving sublethal infections become resistant to subsequent challenge (Hines and Spira, 1974; Houghton and Matthews, 1986).

One promising approach for controlling certain diseases is to strengthen the immune defence mechanisms of fish by the prophylactic administration of immunostimulants (Gannam and Schrock, 2001; Ringø et al., 2011). Nonspecific immunostimulants have attracted wide attention, since they are easily incorporated in the diet and have low impact on the environment (Bricknell and Dalmo, 2005). The polysaccharide $\beta$-glucan is known to activate innate immune mechanisms of various animals including fish (Reynolds et al., 1980; Selvaraj et al., 2005; Rychlik et al., 2013). In nature, $\beta$-glucans are widespread and have been characterised in microorganisms, algae, fungi, and plants (Zekovic et al., 2005). Similarly, it was proven that propolis, a resinous substance produced by honeybees, and especially its most active component, flavanone pinocembrin, has antimicrobial and immunostimulant activity (Abd-El-Rhman, 2009).

The role of immunostimulants as dietary additives in the susceptibility to white spot disease has been investigated in cultured fish species. Studies on rainbow trout (Oncorhynchus mykiss) indicated a certain short-term and a less characterised long-term effect (Lauridsen and Buchmann, 2010) and dose dependency (Jaafar et al., 2011) of yeast-derived $\beta$-glucan on the susceptibility of rainbow trout to Ich. To enhance the innate immunity of common carp (Cyprinus carpio Linnaeus, 1758) against bacterial infections caused by Aeromonas hydrophila, various dietary immunostimulants such as nucleotides (Sakai et al., 2001), Spirulina algae (Watanuki et al., 2006), whole cell yeast, $\beta$-1,3-glucan (Gopalakannan and Arul, 2010), Baker's yeast extract (Biswas et al., 2012) and herbs (Yin et al., 2009) have been tested hitherto. All of these substances showed an immunostimulatory effect against $A$. hydrophila and their application in aquaculture was suggested.

Common carp is a commercially important fish species and its culturing suffers from a wide variety of diseases including white spot disease (Eiras et al., 2008; Sellyei et al., 2017). At present no information is available on the efficacy of $\beta$-glucans or propolis in common carp against Ich infection. The aim of the present study was to test the effect of orally administered propolis extract E50 and yeast-derived $\beta-1,3 / 1,6$-glucan on the susceptibility of common carp fingerlings to white spot disease. 


\section{Materials and methods}

\section{Source of fish and parasites}

Specific pathogen-free (SPF) common carp were laboratory-reared from fertilised eggs obtained from a fish farm in Hortobágy, Hungary. Fish were kept in aerated glass tanks at $20^{\circ} \mathrm{C}$, and fed on commercial ornamental fish food ad libitum on a daily basis.

Ich trophonts were collected from naturally infected roach (Rutilus rutilus), bleak (Alburnus alburnus) and rudd (Scardinius erythrophthalmus) specimens caught in fish ponds by line fishing. Live fish were transported to the laboratory in aerated barrels, and kept at $20^{\circ} \mathrm{C}$ for a few days to enable the parasite trophonts to develop. Fish were killed with an overdose of MS222 (SigmaAldrich, Hungary) solution. Trophonts were collected from skin scrapings, placed in 6-well plates and incubated at room temperature overnight. The trophonts settled and developed hundreds of tomites per trophont/tomont. The free-swimming theronts were harvested the following day. The number of theronts was counted in three replicates in a Bürker chamber with phase contrast microscopy.

\section{Experimental fish diet}

Control fish were fed with $3 \mathrm{~mm}$ Aller Aqua Allermaster grower feed (Aller Aqua, Hungary) that contained $35 \%$ crude protein, $9 \%$ crude fat, $37 \%$ NFE, $4.6 \%$ fibre, $9 \% \mathrm{P}$ and $6.9 \%$ ash. The pellet was homogenised and re-formatted to $2 \mathrm{~mm}$ diameter under the addition of $1.65 \%$ bacteriological agar powder (VWR, USA) and $0.5 \% \mathrm{TiO}_{2}$ (Sigma-Aldrich, Hungary). The re-formatted pellets were considered to be homogeneous after subsequent $\mathrm{TiO}_{2}$ content determination following the method by Brandt and Allam (1987). To the pellets of the control group, no extra active component was added. Experimental fish diet were composed similarly, but they were enriched with dietary immunostimulants, 3\% yeast-derived APG 3-6 $\beta$-glucan (Biothera, USA) and 1\% propolis extract E50 (Propolis Drops containing $70 \mathrm{mg} / \mathrm{g}$ Propolis extractum E50; Naturland, Hungary), respectively.

\section{Experimental design}

In total, 122 common carp were used in the feeding experiment. Common carp individuals aged $>1$ year were randomly separated into three experimental groups of 40-42 individuals each. Groups were fed with control diet, pellets containing 3\% $\beta$-glucan, and pellets with $1 \%$ propolis extract E50, respectively. Fish were fed with the experimental diets at a rate of $1 \%$ of body weight $\mathrm{kg}$ per day until the end of the experiment.

Sampling was conducted on days 5, 10, 15 and 40 . At the first three sampling points (on days 5, 10 and 15) 9 fish were sampled per group, whereas at the fourth sampling point (day 40) 5 fish were sampled per group. Fish were eu- 
thanised with $100 \mathrm{mg} / 1 \mathrm{MS} 222$, killed by cranial severance, and dissected under a stereomicroscope. Liver samples were fixed in RNAlater (Sigma-Aldrich, Hungary) and stored at $-20^{\circ} \mathrm{C}$ until RNA extraction.

\section{Challenge infection and counting trophonts}

Forty days after feeding with experimental diets, 16 fish per group were individually exposed to 2000 Ich theronts/fish in 500-ml beakers for $2 \mathrm{~h}$. Subsequently, they were transferred into 50-1 aerated aquaria (separated by experimental groups) and fed with experimental diet. Five days post exposure (p.e.), fish were anesthetised in $200 \mathrm{mg} / 1 \mathrm{MS} 222$ solution; then killed by cranial severance. The number of trophonts was counted on the lateral body (including the head) and the fins (caudal, back and pectoral fins) of all exposed fish specimens using compound microscopy.

\section{Isolation of RNA and cDNA synthesis}

Approximately $30-50 \mathrm{mg}$ of liver tissue was used for RNA extraction. Tissue samples were homogenised with a Tissue Lyser II (Qiagen Inc., USA), and total RNA was isolated using the RNeasy Mini Kit (Qiagen Inc., USA) following the manufacturer's protocol. DNase treatment using a RNase-Free DNase Set (Qiagen Inc., CA) was performed on-column during RNA isolation in order to eliminate genomic DNA. RNA concentration and purity were measured using a spectrophotometer (NanoDrop 2000, Thermo Scientific, USA). Copy DNA (cDNA) was synthesised with the ExiLERATE LNA cDNA Synthesis kit (Exiqon, Denmark) following the manufacturer's instructions. Subsequently, the synthesised cDNA of all samples was diluted to $100 \mathrm{ng} / \mu 1$ concentrations with RNase-free water and stored at $-80{ }^{\circ} \mathrm{C}$ until further use.

\section{Quantitative real-time PCR ( $q P C R)$ and gene expression analysis}

The relative expression of the immune molecule encoding cytokine interleukin 1- $\beta$ (IL-1- $\beta$ ) gene was measured. Elongation factor 1- $\alpha$ (ELF1- $\alpha)$ was used as endogenous control (i.e. reference gene). Reactions were run and analysed on a Rotor-Gene 6000 real-time rotary analyser (Corbett Life Science, Australia). Standard curves were obtained using synthesised DNA of the genes of interest (i.e. gBlocks Gene Fragments, synthesised by IDT, USA). The cycling conditions were one cycle of initial denaturation at $95{ }^{\circ} \mathrm{C}$ for 15 min followed by 40 cycles of denaturation at $95{ }^{\circ} \mathrm{C}$ for $15 \mathrm{sec}$ and combined annealing and elongation at $60{ }^{\circ} \mathrm{C}$ for $1 \mathrm{~min}$ with endpoint measurement. A QuantiTect Probe RTPCR Kit (Qiagen Inc., USA) was used for multiplex qPCR. Reaction volumes were $15 \mu \mathrm{l}$, consisting of 1x QuantiTect Probe Master Mix (including HotStarTaq DNA Polymerase, QuantiTect Probe RT-PCR Buffer, dNTP mix, ROX passive reference dye, $4 \mathrm{mM} \mathrm{MgCl}{ }_{2}$ ), $0.53 \mu \mathrm{M}$ forward primer (IL-1- $\left.\beta-\mathrm{F}\right), 0.53 \mu \mathrm{M}$ 
reverse primer (IL-1- $\beta$-R), $0.4 \mu \mathrm{M}$ probe (IL-1- $\beta-\mathrm{P}$ ), $0.4 \mu \mathrm{M}$ forward primer (ELF1- $\alpha-F), 0.4 \mu \mathrm{M}$ reverse primer (ELF1- $\alpha-\mathrm{R}), 0.06 \mu \mathrm{M}$ probe (ELF1- $\alpha-\mathrm{P}$ ), $200 \mathrm{ng}$ cDNA and $2 \mu \mathrm{l}$ DNase-free water. The primers and Taqman probes developed, optimised and used for qPCR assays in the present study are listed in Table 1 . The baselines and thresholds were manually set following visual examination of every run. Raw Ct (threshold cycle) values were calculated with the software Rotor-Gene Q version 2.3.1 (Qiagen Inc., USA). Ct values were not recorded when the curves did not reach the threshold value after 40 cycles. Gene expression data were normalised to the reference gene, and inter-run calibration was performed with qBasePlus (Hellemans et al., 2007) to avoid the effect of amplification efficiency differences among different qPCR runs. Raw Ct data from Rotor-Gene Q version 2.3.1 were imported into qBasePlus to calculate the calibrated normalised relative quantities (CNRQ values) of the target genes. The CNRQ value represented the relative gene expression level of the target gene compared to the expression level of the gene used for normalisation (in this case, ELF1- $\alpha$ ). Besides, run- and gene-specific calibration factors were also used to obtain the final CNRQ values. Every replicate that exceeded the maximum replicate variability (threshold value $=1$ ) was excluded from further analysis $(n=17)$.

\section{Table 1}

qPCR oligonucleotides and probes designed and optimised in the present study. Primers and probes were designed based on common carp sequences of interleukin 1- $\beta$ (IL-1- $\beta$ ) as a target and elongation factor 1- $\alpha$ (ELF1- $\alpha)$ as a reference gene was implemented from GenBank. Probes were labelled with 5 ' reporter fluorochrome (HEX or 6-FAM), an internal quencher (ZEN), and a 3 ' dark quencher (Iowa Black FQ, IABkFQ)

\begin{tabular}{|c|c|c|c|c|}
\hline Gene & Primer sequence & Probe & $\begin{array}{l}\text { GenBank } \\
\text { reference }\end{array}$ & $\begin{array}{l}\text { Amplicon } \\
\text { size } \\
\text { (bp) }\end{array}$ \\
\hline ELF1- $\alpha$ & $\begin{array}{l}\text { F: 5'-TGGAGAGCTTCTCTACCTACC-3' } \\
\text { R: 5'-TGATGACACCAACAGCTACG-3' }\end{array}$ & $\begin{array}{l}\text { 5'-HEX-CGCTTTGCT/ } \\
\text { ZEN/ } \\
\text { GTGCGTGACATGAG-3'- } \\
\text { IABkFQ }\end{array}$ & AF485331 & 81 \\
\hline IL-1- $\beta$ & $\begin{array}{l}\text { F: 5'-AAGGAGGCCAGTGGCTCTGT-3' } \\
\text { R: 5'-CCTGAAGAAGAGGAGGCTGTCA-3' }\end{array}$ & $\begin{array}{l}\text { 5'-6-FAM- } \\
\text { ACCATTAAA/ZEN/ } \\
\text { GCCGGTGACCCGAA-3'- } \\
\text { IABkFQ/ }\end{array}$ & AB010701 & 69 \\
\hline
\end{tabular}

\section{Statistical analysis}

Ich infection data were corrected for the body length of the fish individual, i.e. the number of white spots was divided by the length of the body. To obtain normal distribution, data were square-root transformed. One-way ANOVA was used to measure the effect of treatment on the number of trophonts on body 
parts, and Dunnett's post-hoc test was applied to compare treated groups to the control. To examine the effect of treatment and location of Ich trophonts in the same model, multivariate linear regression was used.

For the statistical analyses of the expression of IL-1- $\beta$, gene expression, data were $\log 10$ transformed. Differences among experimental groups or sampling points (days 5, 10, 15 and 40) were analysed with one-way ANOVA. If a significant difference was detected, Dunnett's (for experimental groups) or Tukey's (for sampling points) post-hoc test was used. The effect of treatment was tested for the whole dataset and also for subsets divided by sampling points. All statistical analyses were performed with the R software, version 3.3.3 (R Core Team, 2017), and the 'multcomp' package was used for post-hoc tests (Hothorn et al., 2008).

Table 2

Spatial distribution of Ichthyophthirius multifiliis (Ich) trophonts on the exposed common carp individuals ( $\mathrm{n}=$ number of fish individuals exposed)

\begin{tabular}{|c|c|c|c|c|c|c|c|c|}
\hline $\begin{array}{l}\text { Experimental } \\
\text { group }\end{array}$ & Body part & Min. & Median & Mean & Max. & SD & $\mathrm{N}$ & $\begin{array}{c}\text { Prevalence } \\
(\%)\end{array}$ \\
\hline \multirow[t]{5}{*}{ Control } & Lateral body & 3 & 17 & 15.75 & 30 & 8.87 & 16 & 100 \\
\hline & Caudal fin & 9 & 24 & 25.81 & 55 & 13.22 & 16 & 100 \\
\hline & Back fin & 1 & 5.5 & 6.69 & 20 & 4.57 & 16 & 100 \\
\hline & Pectoral fin & 0 & 1 & 1.19 & 6 & 1.47 & 16 & 69 \\
\hline & $\sum$ & 14 & 45 & 49.44 & 102 & 24.22 & 16 & 100 \\
\hline \multirow[t]{5}{*}{$\beta$-glucan } & Lateral body & 8 & 17.5 & 18.81 & 36 & 9.80 & 16 & 100 \\
\hline & Caudal fin & 4 & 17.5 & 19.19 & 47 & 13.11 & 16 & 100 \\
\hline & Back fin & 1 & 5.5 & 6.25 & 19 & 4.82 & 16 & 100 \\
\hline & Pectoral fin & 0 & 1 & 1.81 & 6 & 1.72 & 16 & 81 \\
\hline & $\sum$ & 19 & 41.5 & 46.06 & 93 & 21.85 & 16 & 100 \\
\hline \multirow[t]{5}{*}{ Propolis } & Lateral body & 0 & 15 & 15.56 & 32 & 8.64 & 16 & 94 \\
\hline & Caudal fin & 2 & 18 & 16.38 & 38 & 10.14 & 16 & 100 \\
\hline & Back fin & 0 & 4.5 & 4.56 & 12 & 3.48 & 16 & 94 \\
\hline & Pectoral fin & 0 & 0 & 1 & 6 & 1.63 & 16 & 44 \\
\hline & $\sum$ & 4 & 37.5 & 37.5 & 78 & 19.19 & 16 & 100 \\
\hline
\end{tabular}

\section{Results}

\section{Ich infection and the effect of additives}

All exposed fish obtained infection following parasite exposure. The mean intensity of Ich infection was the highest in the control group, and the lowest in the treated group fed with propolis additive (Table 2). Significant differences were not detectable $(\mathrm{P}>0.05)$ in regard of body parts between experimental groups and control group with one-way ANOVA (Fig. 1). However, in the propolis-fed 
group, the number of trophonts in the caudal fin $(\mathrm{P}=0.07)$ of common carp showed a distinct trend towards significance (Fig. 2).

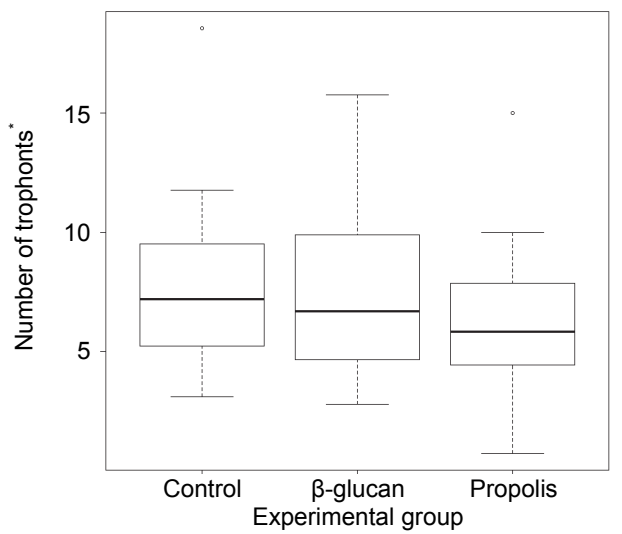

Fig. 1. Comparison of the number of Ichthyophthirius multifiliis (Ich) trophonts between the treated groups and the control group. Boxes represent the interquartile range between first and third quartiles. Bold line in the box is the median. ${ }^{*}$ Values are normalised to the body length of fish

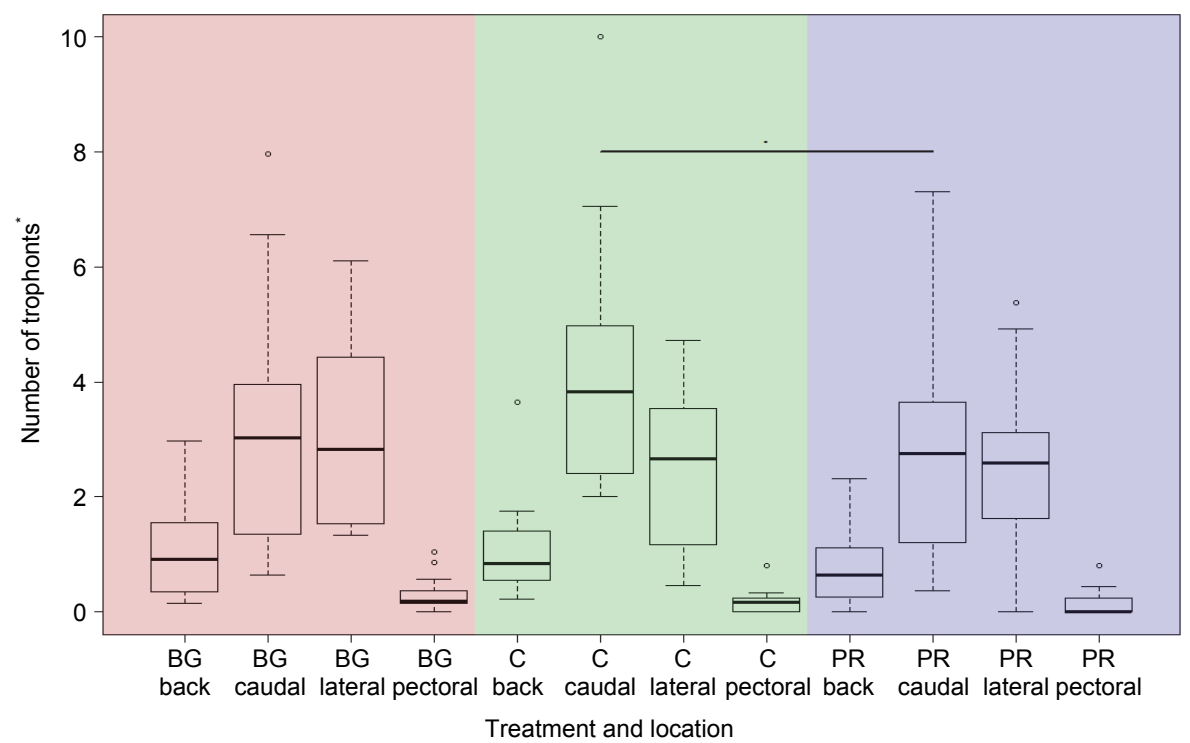

Fig. 2. Infection intensity of experimentally exposed common carp groups represented by the number of Ichthyophthirius multifiliis (Ich) trophonts per body part. A trend toward significance was detected between the caudal fin of common carp in the PR and the control group (horizontal line on the top; $\mathrm{P}=0.07$ ). Boxes represent the interquartile range between first and third quartiles and the bold line in the box is the median. $\mathrm{BG}=\beta$-glucan, $\mathrm{C}=$ control, $\mathrm{PR}=$ propolis extract $\mathrm{E} 50$; back $=$ back fin, caudal $=$ caudal fin, lateral $=$ lateral body parts including head, pectoral $=$ pectoral fin. ${ }^{*}$ Values are normalised to the body length of fish 
Relative gene expression of IL-1- $\beta$

The relative expression of the cytokine IL-1- $\beta$ gene in the liver of common carp was analysed in 104 individuals. One sample out of 122 did not reach the threshold value after 40 cycles in qPCR; furthermore, 17 samples exceeded the maximum replicate variability; therefore, they were excluded from further analysis. Notable down-regulation was detected in the relative expression of IL-1- $\beta$ of the $\beta$-glucan $(\mathrm{P}=0.084)$ and propolis $(\mathrm{P}=0.079)$ groups compared to control (Table 3, Fig. 3); however, the difference was not statistically significant. The relative expression of IL-1- $\beta$ was significantly lower in the propolis-fed group $(\mathrm{P}=0.037)$ at day 10 compared to the control (Fig. 4). Similarly, significant down-regulation $(\mathrm{P}=0.013)$ was detected in the $\beta$-glucan-fed group at day 15 in comparison to the control (Fig. 4). Using Tukey's post-hoc test, the pairwise comparison of IL-1- $\beta$ expression levels within experimental groups and between sampling points showed significant differences in several relations (Table 4). Significant decrease was detected in the IL-1- $\beta$ expression of the control group between day 10 and day 15 (P $=0.033)$, whereas a significant increase was observed between days 15 and $40(\mathrm{P}<$ 0.001 ) (Table 4). In the $\beta$-glucan-fed group, we found a significant decrease between days 5 and $15(\mathrm{P}<0.001)$ and days 10 and $15(\mathrm{P}=0.032)$. A significant increase was detected between days 15 and 40 just as for the control group $(\mathrm{P}<$ $0.001)$. The expression profile in the propolis-fed group was similar to the other groups with slight differences in significance (Table 4, Fig. 4).

Table 3

Calibrated normalised relative quantities (CNRQ values) of interleukin 1- $\beta$ (IL-1- $\beta$ ) gene in experimental groups at different sampling points calculated with the software $\mathrm{qBasePlus}$. Elongation factor $1-\alpha($ ELF1- $\alpha)$ was used as reference gene $(n=$ number of fish individuals examined $)$

\begin{tabular}{lccccccr}
\hline $\begin{array}{l}\text { Experimental } \\
\text { group }\end{array}$ & $\begin{array}{c}\text { Sampling } \\
\text { point }\end{array}$ & Min. & Median & Mean & Max. & SD & N \\
\hline Control & 5 & 0.41 & 0.76 & 0.68 & 0.91 & 0.19 & 9 \\
& 10 & 0.07 & 0.71 & 0.74 & 1.29 & 0.35 & 9 \\
& 15 & 0.02 & 0.21 & 0.26 & 0.81 & 0.24 & 12 \\
& 40 & 0 & 1.22 & 1.05 & 1.82 & 0.61 & 10 \\
& $\Sigma$ & 0 & 0.69 & 0.66 & 1.82 & 0.47 & 40 \\
\hline$\beta$-glucan & 5 & 0.19 & 0.72 & 0.69 & 1.14 & 0.33 & 9 \\
& 10 & -0.2 & 0.28 & 0.41 & 1.6 & 0.56 & 9 \\
& 15 & -1.04 & -0.21 & -0.24 & 0.53 & 0.49 & 13 \\
& 40 & 0.74 & 0.87 & 1.1 & 1.91 & 0.47 & 10 \\
\hline Propolis & $\Sigma$ & -1.04 & 0.44 & 0.42 & 1.91 & 0.67 & 41 \\
& 5 & 0.2 & 0.74 & 0.67 & 1.19 & 0.38 & 9 \\
& 10 & -0.09 & 0.23 & 0.25 & 0.48 & 0.17 & 9 \\
& 15 & -0.32 & 0.16 & 0.12 & 0.66 & 0.34 & 12 \\
& 40 & 0.56 & 0.66 & 0.71 & 1.06 & 0.17 & 10 \\
& $\Sigma$ & -0.32 & 0.42 & 0.42 & 1.19 & 0.38 & 40 \\
\hline
\end{tabular}




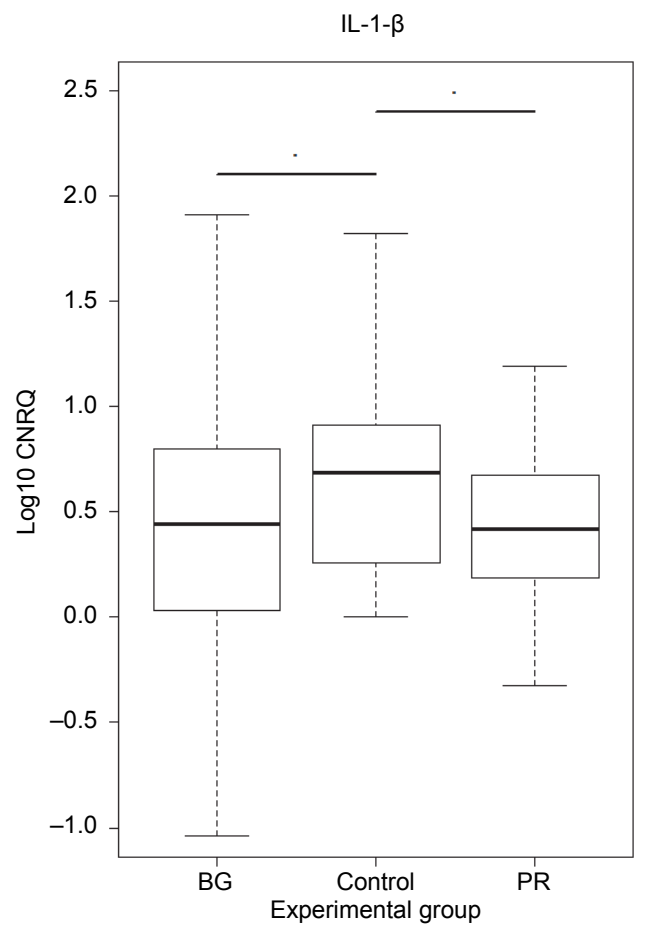

Fig. 3. Relative expression of the interleukin 1- $\beta$ (IL-1- $\beta$ ) gene in the liver samples of common carp visualised as $\log 10$ transformed, calibrated normalised relative quantities $(\log 10 \mathrm{CNRQ}$ values). The relative expression of the IL-1- $\beta$ gene was statistically compared between the treated groups (BG and PR) and the control group (horizontal lines on the top; $\mathrm{P}=0.084$ and 0.079 , respectively). Boxes represent the interquartile range between first and third quartiles.

Bold line in the box is the median. $\mathrm{BG}=\beta$-glucan, $\mathrm{PR}=$ propolis extract $\mathrm{E} 50$

\section{Table 4}

$P$ values obtained with the pairwise comparison of the expression level of interleukin 1- $\beta$ (IL-1- $\beta$ ) gene within experimental groups and between sampling points using Tukey's post-hoc test. Sampling was conducted on days 5,10,15 and 40. Significant differences are indicated in bold. Levels of significance: ${ }^{*}=\mathrm{P}<0.05,{ }^{* *}=\mathrm{P}<0.01,{ }^{* * *}=\mathrm{P}<0.001$

\begin{tabular}{|c|c|c|c|c|c|}
\hline \multicolumn{2}{|c|}{ Control } & \multicolumn{2}{|c|}{$\beta$-glucan } & \multicolumn{2}{|c|}{ Propolis } \\
\hline $\begin{array}{l}\text { Compared } \\
\text { sampling } \\
\text { points }\end{array}$ & $P$ value & $\begin{array}{l}\text { Compared } \\
\text { sampling } \\
\text { points }\end{array}$ & $P$ value & $\begin{array}{l}\text { Compared } \\
\text { sampling } \\
\text { points }\end{array}$ & $\mathrm{P}$ value \\
\hline $10-5$ & 0.987 & $10-5$ & 0.609 & $10-5$ & $0.02^{*}$ \\
\hline $15-5$ & 0.073 & $15-5$ & $<0.001^{* * * *}$ & $15-5$ & $0.001^{* *}$ \\
\hline $40-5$ & 0.179 & $40-5$ & 0.369 & $40-5$ & 0.993 \\
\hline $15-10$ & $0.033^{*}$ & $15-10$ & $0.032^{*}$ & $15-10$ & 0.76 \\
\hline $40-10$ & 0.313 & $40-10$ & 0.05 & $40-10$ & $0.012^{*}$ \\
\hline $40-15$ & $<0.0011^{* * * *}$ & $40-15$ & $<0.001^{* * * *}$ & $40-15$ & $<0.001$ \\
\hline
\end{tabular}




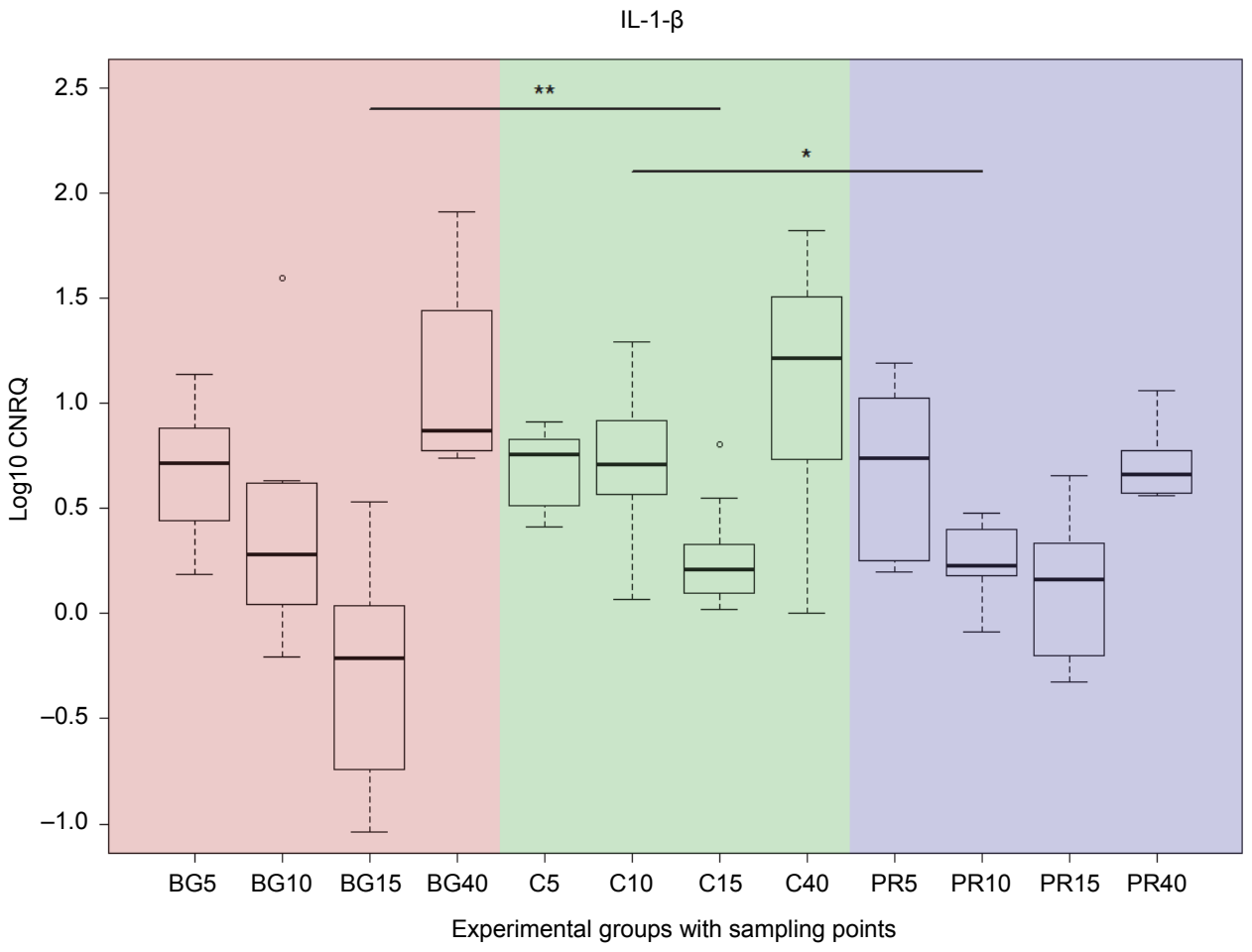

Fig. 4. Relative expression of the interleukin 1- $\beta$ (IL-1- $\beta$ ) gene in the liver of common carp. The relative gene expression was significantly decreased in the propolis-fed group at the second sampling point $(\mathrm{PR} 10, \mathrm{P}=0.037)$ and in the $\beta$-glucan fed group at the third sampling point $(\mathrm{BG} 15$, $\mathrm{P}=0.013$ ) compared to the control. Calibrated normalised relative quantities (CNRQ values) were $\log 10$ transformed. Boxes represent the interquartile range between first and third quartiles. Bold line in the box is the median. The $\mathrm{X}$-axis represents the days of feeding (e.g. sampling points on days $5,10,15$ and 40$)$. $\mathrm{BG}=\beta$-glucan, $\mathrm{C}=$ control, $\mathrm{PR}=$ propolis extract $\mathrm{E} 50$. Levels of significance: ${ }^{*}=\mathrm{P}<0.05,{ }^{* *}=\mathrm{P}<0.01$ (shown by the horizontal lines on the top)

\section{Discussion}

The immunostimulant effect of $\beta$-glucans is largely dependent on their chemical composition (Bohn and BeMiller, 1995), dosage (Jaafar et al., 2011) and mode of administration (Selvaraj et al., 2005). Most of these parameters greatly vary between target fish species. A previous study emphasised that intraperitoneal injection of yeast-derived $\beta$-glucan in common carp improved resistance to infection against Aeromonas hydrophila; however, oral administration of the same substance did not induce any effect (Selvaraj et al., 2005). In the present experiment, we used orally administered $\beta-1,3 / 1,6$-glucan and propolis extract E50 food additives to test for infection intensity differences between the 
immunostimulated groups and control carp exposed to Ich theronts. Jaafar et al. (2011) examined the dose dependency of the water-insoluble, $\beta$-1,3-glucan (paramylon) from the alga Euglena gracilis, and found that the 5\% concentration administered over a long period (45 days) was significantly more effective in reducing the number of Ich trophonts in rainbow trout than lower concentrations $(0 \%, 0.2 \%$ and $2 \%$, respectively). Based on these findings, we used $3 \%$ concentration of water-soluble, yeast-derived $\beta-1,3 / 1,6$-glucan for a 40 -day-long administration. The application of $\beta$-glucans in higher concentrations, i.e. $1800 \mu \mathrm{g} /$ fish in Atlantic salmon, Salmo salar as a food additive may cause unfavourable effects such as an overdose expressed as increased phagocytic disability of cells (caused by overloading of glucan particles), and is considered not to be effective against the bacterium Vibrio anguillarum (Robertsen et al., 1990). Besides, the administration of higher concentrations $(<5 \%)$ of high-purity $\beta$-glucans for extended periods of time is commercially not profitable for regular fish farms. Our findings obtained with a medium-level (i.e. $3 \%$ ) $\beta$-glucan concentration showed decreased number of Ich trophonts compared to the control group, but the treated fish got infected with as high prevalence as the control. Thus, the protective effect of $\beta$-glucan against Ich in common carp could not be confirmed in our experiment.

Among other properties, the antiviral, antifungal and antibacterial effect of propolis is well studied in different organisms including fish (Bankova et al., 2000). In rainbow trout, a prolonged administration of propolis as a food additive did not have any side effects for development and serum biochemical parameters (Kashkooli et al., 2011), but their short term effect showed significant changes in some of the haematological variables (Talas and Gulhan, 2009). Using propolis as food additive, a previous study found that the ethanolic extract of propolis in $1 \%$ concentration enhanced the growth, immunity and resistance of Nile tilapia, Oreochromis niloticus against A. hydrophila (Abd-El-Rhman, 2009). In our study, $1 \%$ propolis ethanolic extract (E50) administered orally reduced the overall number of Ich trophonts on fish, and the difference in infection intensity compared to the control group was slightly below significance $(P=0.07)$ only in a certain body part (the caudal fin) of infected common carp.

Besides the susceptibility of fish to white spot disease measured with the Ich infection intensity, we examined the immune response of common carp by measuring the relative expression level of the cytokine interleukin 1- $\beta$ (IL-1- $\beta$ ) gene in liver samples. IL-1- $\beta$ is a pleiotropic paracrine and endocrine signalling molecule, which is produced by a variety of cell types. As an important regulating factor, it guides the immune response after external or internal challenges. Moreover, it activates the proliferation of lymphocytes as T and B cells, as well as the cytotoxic activity of natural killer cells and macrophages (Dower and Sims, 1994). Our results show that the relative expression level of IL-1- $\beta$ decreased in the first two weeks of feeding, and it considerably increased prior to 
Ich exposure on day 40 . Nevertheless, the expression profile did not show significant differences between experimental groups and the control group. On the other hand, when we analysed the subset of the obtained relative expression data, and examined the difference between experimental groups and sampling points, we found a significant down-regulation compared to the control in the $\beta$-glucanfed group after 15 days. Jaafar et al. (2011) experienced a moderate IL-1- $\beta$ expression in rainbow trout against Ich infection at the start of their feeding experiment, and the expression of that signal molecule was down-regulated until the end of their experiment. Our results displayed a very similar gene expression pattern both in the $\beta$-glucan- and the propolis-treated groups.

Propolis and its isolated compounds may be useful in different pathological conditions such as infections, allergy, tumors and ulcers, but the effect on ectoparasites, such as Ich, has not been investigated yet. Dotta et al. (2015) studied the effect of diet supplementation with the admixture of propolis and aloe, Aloe barbadensis on haematological parameters (i.e. haematocrit, red blood cell, white blood cell and thrombocyte counts) and monogenean parasite infection in Oreochromis niloticus. The highest efficiency against the parasites was observed after 15 days of feeding with $0.5 \%$ and $1 \%$ propolis-aloe mixture. After 21 days of feeding with the experimental diet with $0.5 \%$ propolis-aloe extract, significant increases were found in all haematological parameters except the number of red blood cells. Besides, the experimental diet with $1 \%$ substance displayed a significant increase in white blood cells, lymphocytes and neutrophils after 21 days of administration. Our findings showed a moderate but not significant $(P=0.079)$ overall down-regulation of IL-1- $\beta$ in the propolis-fed group, compared to the control fish.

This is the first time that yeast-derived $\beta$-glucan and propolis extract E50 were studied for their potential ability to mitigate Ich infection in common carp as food additives. Although our results show that infection intensity was slightly lower in groups fed with the examined substances, and cytokine IL-1- $\beta$ was moderately down-regulated compared to the control, the applied feeding regime was insufficient for a successful practical use against white spot disease in fish farms. Nevertheless, used in different application regimes or in combination with other preventive measures (i.e. temperature and water flow regulation or use of disinfectants), such food additives might become relevant prophylactic means in aquaculture disease control practice.

\section{Acknowledgements}

Thanks are due to Gergely Zsigmond for the preparation of experimental fish pellets, and to Prof. Dr. Tibor Dublecz for the determination of $\mathrm{TiO}_{2}$ concentration in the experimental fish pellets. The work was supported by the grant Aquafuture (Nr. VKSZ_12-1-2013-0078). 


\section{References}

Abd-El-Rhman, A. M. M. (2009): Antagonism of Aeromonas hydrophila by propolis and its effect on the performance of Nile tilapia, Oreochromis niloticus. Fish Shellfish Immunol. 27, 454-459.

Bankova, V. S., De Castro, S. L. and Marcucci, M. C. (2000): Propolis: recent advances in chemistry and plant origin. Apidologie 31, 3-15.

Biswas, G., Korenaga, H., Takayama, H., Kono, T., Shimokawa, H. and Sakai, M. (2012): Cytokine responses in the common carp, Cyprinus carpio L. treated with baker's yeast extract. Aquaculture 356-357, 169-175.

Bohn, J. A. and BeMiller, J. N. (1995): (1-3)- $\beta$-D-glucans as biological response modifiers: a review of structure-functional activity relationships. Carbohydr. Polymers 28, 3-14.

Brandt, M. and Allam, S. M. (1987): Analytik von $\mathrm{TiO}_{2}$ im Darminhalt und Kot nach Kjeldahlaufschluß. Arch. Anim. Nut. 37, 453-454.

Bricknell, I. and Dalmo, R. A. (2005): The use of immunostimulants in fish larval aquaculture. Fish Shellfish Immunol. 19, 457-472.

Dotta, G., Brum, A., Jerônimo, G. T., Maraschin, M. and Martins, M. L. (2015): Dietary supplementation with propolis and Aloe barbadensis extracts on the hematological parameters and parasitism in Nile tilapia. Braz. J. Vet. Parasitol. 24, 66-71.

Dower, S. K. and Sims, J. E. (1994): Interleukin-1 receptor antagonist (IL-1 $\alpha$, IL-1 $\beta$, and IL-1Ra). In: Nicola, N. A. (ed.) Guidebook to Cytokines and their Receptors. Oxford University Press, New York, USA. pp. 17-22.

Eiras, J. C., Segner, H., Wahli, T. and Kapoor, G. B. (2008): Fish Diseases, Volumes 1 and 2. Science Publishers, Enfield, Jersey, Plymouth; ISBN (set): 978-1-57808-438-8.

Gannam, A. L. and Schrock, R. M. (2001): Immunostimulants in fish diets. In: Lim, C. and Webster, C. D. (eds) Nutrition and Fish Health. Haworth Press, New York, USA. pp. 235-266.

Gopalakannan, A. and Arul, V. (2010): Enhancement of the innate immune system and diseaseresistant activity in Cyprinus carpio by oral administration of beta-glucan and whole cell yeast. Aquac. Res. 41, 884-892.

Hellemans, J., Mortier, G., De Paepe, A., Speleman, F. and Vandesompele, J. (2007): qBase relative quantification framework and software for management and automated analysis of real-time quantitative PCR data. Genome Biol. 8, R19.

Hines, R. S. and Spira, D. T. (1974): Ichthyophthiriasis in the mirror carp Cyprinus carpio (L.) III. Pathology. J. Fish Biol. 6, 189-196.

Hothorn, T., Bretz, F. and Westfall, P. (2008): Simultaneous inference in general parametric models. Biom J. 50, 346-363.

Houghton, G. and Matthews, R. A. (1986): Immunosuppression of carp (Cyprinus carpio L.) to ichthyophthiriasis using the corticosteroid triamcinolone acetonide. Vet. Immunol. Immunopathol. 12, 413-419.

Jaafar, R. M., Skov, J., Kania, P. W. and Buchmann, K. (2011): Dose dependent effects of dietary immunostimulants on rainbow trout immune parameters and susceptibility to the parasite Ichthyophthirius multifiliis. J. Aquac. Res. Development S3, 001.

Kashkooli, O. B., Dorcheh, E. E., Mahboobi-Soofiani, N. and Samie, A. (2011): Long-term effects of propolis on serum biochemical parameters of rainbow trout (Oncorhynchus mykiss). Ecotoxicol. Environ. Saf. 74, 315-318.

Lauridsen, J. H. and Buchmann, K. (2010): Effects of short- and long-term glucan feeding of rainbow trout on the susceptibility to Ichthyophthirius multifiliis infections. Acta Ichthyol. Piscat. 40, 61-66.

Matthews, R. A. (2005): Ichthyophthirius multifiliis Fouquet and ichthyophthiriosis in freshwater teleosts. Adv. Parasit. 59, 159-241. 
R Core Team (2017): R: A language and environment for statistical computing. R Foundation for Statistical Computing, Vienna, Austria. URL http://www.R-project.org/.

Reynolds, J. A., Kastello, M. D., Harrington, D. G., Crabbs, C. L., Peters, C. J., Jemski, J. V., Scott, G. H. and Di Luzio, N. R. (1980): Glucan-induced enhancement of host resistance to selected infectious diseases. Infect. Immun. 30, 51-57.

Ringø, E., Olsen, R. E., Gonzales Vecino, J. L., Wadsworth, S. and Song, S. K. (2012): Use of immunostimulants and nucleotides in aquaculture: A review. J. Marine Sci. Res. Development 2, 104.

Robertsen, B., Rørstad, G., Engstad, R. and Raa, J. (1990): Enhancement of non-specific disease resistance in Atlantic salmon, Salmo salar L., by a glucan from Saccharomyces cerevisiae cell walls. J. Fish Dis. 13, 391-400.

Rychlik, A., Nieradka, R., Kander, M., Nowicki, M., Wdowiak, M. and Kolodziejska-Sawerska, A. (2013): The effectiveness of natural and synthetic immunomodulators in the treatment of inflammatory bowel disease in dogs. Acta Vet. Hung. 61, 297-308.

Sakai, M., Taniguchi, K., Mamoto, K., Ogawa, H. and Tabata, M. (2001): Immunostimulant effects of nucleotide isolated from yeast RNA on carp, Cyprinus carpio L. J. Fish Dis. 24, 433-438.

Sellyei, B., Molnár, K. and Székely, C. (2017): Diverse Chlamydia-like agents associated with epitheliocystis infection in two cyprinid fish species, the common carp (Cyprinus carpio L.) and the gibel carp (Carassius auratus gibelio L.). Acta Vet. Hung. 65, 29-40.

Selvaraj, V., Sampath, K. and Sekar, V. (2005): Administration of yeast glucan enhances survival and some non-specific and specific immune parameters in carp (Cyprinus carpio) infected with Aeromonas hydrophila. Fish Shellfish Immunol. 19, 293-306.

Talas, Z. S. and Gulhan, M. F. (2009): Effects of various propolis concentrations on biochemical and hematological parameters of rainbow trout (Oncorhynchus mykiss). Ecotoxicol. Environ. Saf. 72, 1994-1998.

Watanuki, H., Ota, K., Tassakka, A. C. M. A. R., Kato, T. and Sakai, M. (2006): Immunostimulant effects of dietary Spirulina platensis on carp, Cyprinus carpio. Aquaculture 258, 157-163.

Yin, G., Ardo, L., Thompson, K. D., Adams, A., Jeney, Z. and Jeney, G. (2009): Chinese herbs (Astragalus radix and Ganoderma lucidum) enhance immune response of carp, Cyprinus carpio, and protection against Aeromonas hydrophila. Fish Shellfish Immunol. 26, 140-145.

Zekovic, D. B., Kwiatkowski, S., Vrvic, M. M., Jakovljevic, D. and Moran, C. A. (2005): Natural and modified $(1 \rightarrow 3)$-beta-D-glucans in health promotion and disease alleviation. Crit. Rev. Biotechnol. 25, 205-230. 